\title{
Industrial Relations in
}

\section{the U.S. Automobile}

\section{Industry: An Illustration}

of Increased

\section{Decentralization and}

\section{Diversity}

\section{Harry C. Katz*}

\section{Abstract}

This paper traces the evolution of employment relations in the U.S. auto industry over the post World War II period with particular emphasis on recent developments. There is a strong movement toward growing variation in employment relations within both the assembly and parts sectors of the auto industry. Variation appears both through the spread of more contingent compensation and team systems of work organization. There is also wide variety across plants and industry segments in basic employment systems including low wage, human resource, Japanese-oriented, and joint team-based approaches. Declining unionization is a particularly strong influence in the parts sector although nonunion operations have now spread to the assembly sector. While these trends are well illustrated by developments in the auto industry, they are trends common to other parts of the U.S. economy.

* Jack Sheinkman Professor of Collective Bargaining and Director of the Institute of Collective Bargaining, NYSSILR, Cornell University 


\section{Introduction}

The auto industry has historically played a prominent role in American collective bargaining, introducing many now common features - multi-year contracts with cost-of-living-adjustment escalators and built-in annual real wage increases, supplementary unemployment benefits, ' 30 and out' pensions, and quality of working life (QWL) programs -and upholding a strong structure of pattern bargaining for many years. ${ }^{1}$ In the 1980 s, automotive labor relations was again in the forefront in taking actions to modify this long-established model, under pressure from both foreign and domestic competitors and from new production models linked to new human resource practices.

The cumulative outcome of these pressures has been increased diversity and decentralization of employment relations. Modifications of the industry's collective bargaining model have included so-called 'concessionary' contracts that replace traditional bargaining formulas with company-specific profit-sharing plans and work rule changes; extensive new income and job security programs to cope with industry restructuring; joint labor-management efforts around training and quality; and the use of new work structures at the shop floor level, such as teams combined with very few job classifications, that challenge the principles of 'job control' unionism.

Diversity across companies in industrial relations practices also is being spurred through the expansion of Japanese ownership and influence and the prominence of new models of worker and union participation. As Japanese companies became owners or co-owners (along with American company partners) of new assembly plants, the fact that virtually all of the solelyowned Japanese plants operated without a union introduced the threat of non-union operations to what had been one of the few remaining fully unionized sectors in the American economy. The presence of Japanese plants in the United States also gave impetus to the diffusion of 'lean production', a Toyota-derived model combining new manufacturing methods such as just-in-time inventory systems and statistical process control with new human resource practices focused on worker motivation and multiskilling. Meanwhile, the extreme form of worker and union involvement (even in business decisions) that emerged in the expanding Saturn facility, a subsidiary of General Motors, was viewed by many as an American alternative to (or extension of) lean production, and quickly attracted both proponents and opponents among management and union ranks.

Variation in employment relations in the auto parts sectors includes pressures similar to those found in the assembly sector plus more extensive 
growth in non-union employment. Linked to the deunionization occurring in the auto parts sector is the spread of low wage employment practices.

Before describing these recent developments in automotive industrial relations more fully, the industry and its innovative history of labor-management relations are reviewed. The next section includes a description of the primary parties involved in U.S. automotive labor relations: the unions and the companies. Subsequent sections then focus on the changing nature of industrial relations in the auto assembly and auto parts sectors.

\section{Unions, Companies and the Competitive Environment}

\section{The Unions}

The United Automotive Workers (UAW) is the primary union representing workers in the auto industry. The International Union of Electricians (IUE) also represents some hourly auto workers (primarily in the electrical product parts plants). By the late 1940s the UAW had organized all hourly workers in the companies that assembled cars and trucks. Until 1985, the UAW was an international union as it included Canadian auto workers. In 1985, the Canadian auto workers voted to secede and a separation agreement was negotiated between the U.S. and Canadian parts of the UAW to form the Canadian Auto Workers (CAW).

The UAW is a large and fairly centralized union. The internal structure of the union includes departments organized along company lines in the auto industry and an agricultural implements department. National union staff coordinate bargaining within each department and also assist in the implementation of benefits, employee assistance, health and safety, and quality of working life programs.

The central figure in the union over the post war period was Walter Reuther who along with his brothers was active in the union's sit down strikes and organizing efforts in the 1930s. Reuther served as president of the UAW from 1947 until his death in 1970. During his tenure, Reuther led a coalition (the 'administrative caucus') that dominated the national affairs of the union and while he was alive, Reuther's influence and imagination encouraged an innovative spirit within auto bargaining. Under Reuther's guidance the UAW also was very active in national and local politics and a strong supporter of the Democratic Party. Yet, even with the dominance of the Reuther coalition, the UAW historically has had strong democratic traditions which appeared recently in the debates occurring within the UAW between the 'New Directions Movement' and the 'Administrative Caucus'. These debates are reviewed later in this paper. 


\section{The Companies}

The American assembly companies are commonly referred to as the 'Big Three' - General Motors (GM), Ford, and Chrysler. They produce a number of car and truck parts and they assemble these parts into final vehicles, although the extent to which these assemblers are 'vertically integrated' (use parts produced in their own plants) varies. Estimates of the degree of integration in 1990 are GM-70\%, Ford $-40 \%$, and Chrysler-30\%. The Big Three are completely unionized, and their national (company-wide) collective bargaining agreements cover the companies' final assembly and parts plants. In addition, the Saturn Corporation, a subsidiary of GM, operates a sizeable unionized auto assembly complex in Tennessee, covered under a separate contract that differs substantially from the national GM agreement.

There are also a number of assembly plants with Japanese ownership involvement, referred to in the industry and in this paper as the 'transplants'. Table 1 contains summary information on these plants. The three unionized transplants acquired this status by virtue of their joint venture arrangements with U.S. companies. These arrangements have been somewhat fluid; they

Table 1. Japanese Automobile Assembly Plants Based in the United States

\begin{tabular}{|c|c|c|c|c|c|}
\hline Company & Location & $\begin{array}{l}\text { Product'n } \\
\text { Began }\end{array}$ & $\begin{array}{l}1989 \\
\text { Product'n }\end{array}$ & $\begin{array}{l}1995 \\
\text { Product'n }\end{array}$ & Unio \\
\hline Honda & Marysville, $\mathrm{OH}$ & 1982 & $363,274^{1}$ & $551,533^{1}$ & No \\
\hline Nissan & Smyrna, TN & 1983 & 238,641 & 465,819 & No \\
\hline $\begin{array}{l}\text { New United Motor } \\
\text { Manufacturing } \\
\text { (Toyota and General Motors) }\end{array}$ & Fremont, CA & 1984 & 192,471 & 349,503 & Yes \\
\hline Mazda (with Ford) & Flat Rock, MI & 1987 & 216,501 & $148,932^{2}$ & Yes \\
\hline $\begin{array}{l}\text { Diamond-Star } \\
\text { (Mitsubishi and Chrysler) }\end{array}$ & Normal, IL & 1988 & 90,741 & 218,161 & Yes \\
\hline Toyota & Georgetown, $\mathrm{KY}$ & 1988 & 151,099 & 389,048 & No \\
\hline Subaru-Isuzu & Lafayette, IN & 1989 & 11,160 & 389,048 & No \\
\hline Honda & East Liberty, $\mathrm{OH}$ & 1989 & $\left({ }^{1}\right)$ & $(1)$ & No \\
\hline BMW & Spartansburgh, SC & 1994 & - & 11,876 & No \\
\hline
\end{tabular}

\footnotetext{
${ }^{1}$ Honda Marysville production level includes Honda East Liberty as well.

${ }^{2}$ Mazda production was 246,991 in 1994. Production was slowed in 1995 due to excess inventories.

Sources: Motor Vehicle Manufacturers Association and Automotive News (Detroit, MI., Crain Communications, Inc.), various issues. Christopher J. Singleton 'Auto Industry Jobs in the 1980's: A Decade of Transition,' Monthly Labor Review, Vol. 115, No. 2, February 1992, pp. 18-27. The 1995 figures include cars and trucks and are from an unpublished table compiled by General Motors.
} 
have been altered at two of these plants since they opened. The contracts at these plants, like at Saturn, represent a substantial departure from the national UAW-Big Three agreements. Five of the transplants are non-union plants, and they appear to represent the dominant trend for new investment, with both BMW and Mercedes-Benz now building new non-union plants.

Japanese companies have historically been much less vertically integrated than the Big Three, and this pattern is also true for the transplants. Estimates indicate that Toyota, Nissan, and Mazda are the most vertically integrated of the Japanese companies, at $30 \%$, and that Suzuki is the least vertically integrated, at $16 \%$; the industry average is just under $25 \%$. The transplants initially sourced many of their parts from Japan, but have made a strong effort in recent years, accelerated by political pressures related to the U.S. - Japan trade deficit, to increase the 'local content' of their U.S.-built vehicles.

\section{The Competitive Environment}

From 1946 until 1979, the auto industry in the U.S. was on a prosperous growth path, even in the face of the industry's periodic sharp cyclical swings. Over these years domestic production of cars and trucks increased from 5 to 13 million vehicles. From 1946 to 1979 the number of production workers grew $20 \%$ and periodically fluctuated substantially along with vehicle production. The combination of large vehicle output growth and modest employment growth was due to the significant productivity gains accomplished by the industry. This productivity and output growth helped produce strong profit figures for the industry and provided support for substantial growth in auto workers' real earnings.

From the end of World War II until the late 1970s, the economic environment of the auto industry was conducive to steady improvements and general stability in labor relations. Three environmental factors were critical - growth in domestic auto sales, a low level of imported vehicle sales, and a high degree of unionization. Yet, in the early 1980s, a labor and management that had grown accustomed to long run growth in total vehicle sales and profits were confronted by a number of fundamental changes in the auto market.

One important aspect of the change was an increase in international competition in the form of increased vehicle imports. While the level of imports increased steadily during the 1960 s and 1970 s from a post-war low of $5 \%$ in 1955, it surged during the $1980 \mathrm{~s}$. The total import share of American new car sales rose from $21.9 \%$ in 1979 to $30.7 \%$ in 1987 , before falling back to $26.4 \%$ in 1990 . 
In the early 1980s American auto makers also confronted sizeable declines in sales induced by a sluggish American economy. From 1979 to 1982 employment in the auto industry (SIC 371) declined by $29.4 \%$ (from 990,400 to 699,300 ). Ford and Chrysler were hardest hit during this downturn. Then in mid 1983, auto sales began to rebound strongly and employment in the industry and the financial status of the auto assemblers markedly improved. By 1985 employment had recovered to 883,500; these numbers reflect not only the recovery of the Big Three but also the strong growth in transplant employment during the early 1980s. Profits also rebounded; in 1983 and 1984, the combined profits of the Big Three (GM, Ford and Chrysler) were, respectively, $\$ 6.3$ billion and $\$ 9.8$ billion, and the Big Three continued to be profitable on through the 1990s.

Despite the return to profitability in the mid-1980s, the Big Three faced increasing competition not only from imports but also from the sizeable growth in Japanese transplant auto production. Japanese transplant car sales grew from zero in 1982 to $14.4 \%$ of the U.S. market in 1990, with transplant sales projected to rise to a $20 \%$ share of the American market by the turn of the century.

When a sluggish economy returned in the early 1990s, it had dramatic effects on both employment and profits among the Big Three. By 1991, auto industry employment was down to 789,000; most of this drop reflected job losses for the Big Three, since the transplants continued to bring new capacity on-line during this period. In 1991 financial losses in the core automotive businesses at GM, Ford and Chrysler, respectively were, $\$ 5.2$ billion, $\$ 1.9$ billion, and $\$ 0.8$ billion. GM's losses led to the company's decision to close 22 plants by 1995 and cut white and blue collar employment by 80,000 .

Then in 1993 profits rebounded strongly at the Big Three with Chrysler performing particularly favorably. Along with this sales and profit rebound, employment also rebounded, although not as strongly as the auto companies made extensive use of overtime (particularly at Ford and Chrysler) and benefited from productivity improvements. Some good news for American companies came in the early 1990 s with a small but significant increase in Big Three market share, to $64.4 \%$ in 1992 , brought on by sluggish sales of vehicles imported from Japan, partly due to an unfavorable exchange rate, and the Big Three's successful unveiling of some popular new products and willingness to show price restraint to gain sales.

Even in the face of periodic profit rebounds, the increase in international and domestic competition led to sizeable declines in employment at the Big Three and UAW membership. From 1978 to 1990, the number of hourly 
jobs at the Big Three declined by $39 \%$ (from 740,000 to 455,000 ). Meanwhile, UAW membership declined $37 \%$ from 1979 to 1990 (from $1,510,000$ to 950,000$)^{2}$

In addition to intensified competitive pressures, the economic environment of the U.S. auto assemblers was altered from the 1980 s on through the Big Three's decision to forge coproduction agreements with their Japanese counterparts, as noted above. The primary motivation for the U.S. companies was to fill gaps in their product lines, particularly for small cars. Yet, the Big Three have also been influenced, to varying degrees, by the desire to use these co-owned but Japanese-managed plants to experiment with new production systems and to develop demonstration models for their whollyowned plants. The importance of the transplants for industrial relations arises from the fact that they utilize innovative practices in both work organization, employee involvement, and manufacturing practice (discussed below) and that the plants solely built by the Japanese are unorganized.

Also significant for collective bargaining has been the formation of more extensive linkages between the assembler companies and their parts suppliers. Most assemblers dramatically reduced the number of their parts suppliers and initiated longer term contracts with the select group of suppliers that remained. At the same time, they increased the percentage of the parts purchased from non-captive suppliers through increased outsourcing from their wholly-owned 'inside' suppliers. The immediate effect of this trend was to increase the pressure for cost reduction on the parts plants owned by the assemblers, and to reduce union density in the auto parts sector, since the vertically-integrated suppliers are $100 \%$ unionized, while the U.S.-owned independent sector is about $50 \%$ unionized and the Japanese supplier transplants are nearly $100 \%$ non-union. The formation of stronger links across the assembly companies and between assemblers and parts suppliers eventually also may produce complicated problems regarding bargaining structure and union jurisdiction.

As the level of inventory held by the Big Three dropped during the 1980s, the interdependence of assembler and supplier plants increased dramatically, affecting labor relations in unpredictable ways. For instance, while the lean buffers of Just-In-Time (JIT) provide an incentive for suppliers to avoid labor conflict that might interrupt parts deliveries (and for assemblers to do business with suppliers who can manage labor relations effectively), the greater interdependence between assembly and parts plants also gives a new potential source of strike leverage. 
Analysis of the changing nature of employment relations in the U.S. auto industry requires separate consideration of the assembly and independent parts sector as the timing and extent of non-union growth differs in the two sectors, although there are commonalities in the pattern of developments across the auto industry. The independent parts sector excludes the assembly and parts operations within the Big Three automobile companies and the auto parts production carried out within other companies that include assembly operations (the Japanese and German 'transplant' firms). The Japanese and German transplants have made a significant contribution to the growing variation in employment relations in the U.S. auto industry because the transplants operate on a non-union basis. Furthermore, as described in more detail later, the work practices in the Japanese transplants plants follow a 'Japanese-oriented pattern' and have served as a model for firms in many other industries. The programmatic details of work practice implementation and operation differ significantly across the transplants, contributing another important element to the growing variation in employment relations in the U.S. auto industry.

In the assembly and independent parts sectors, respectively, the diversity in employment relations brought about through the growth of non-union operations is examined first. Then the analysis focuses on the variation that is appearing within the union and non-union sectors. The analysis of within sector variation (union and non-union) distinguishes between the variation appearing in worker earnings and the variation surfacing in work practices.

\section{Industrial Relations in the Auto Assembly Sector}

\section{The Non-union Transplant Challenge to the Big Three}

One of the key sources of growth in variation in the employment relations in auto assembly plants in the United States has been the growth of non-union auto assembly plants. Until the start-up of Japanese owned transplants, the auto assembly sector had remained one of the key completely unionized sectors in the United States. The assembly plants of the Big Three auto companies had been organized in the late 1930s and 1940s by the UAW. Collective bargaining in the Big Three companies then led to substantial growth in the wages and fringe benefits received by auto workers and established the UAW as one of the most pivotal unions in the country.

The union status of the assembly plants in the Big Three was challenged in the 1970s through GM's southern strategy which entailed the opening of non-union plants in the South. However, by the early 1980 s the non-union GM assembly plants in the South were organized, in large part through the 
automatic ('accretion') procedures the UAW won from GM after the union threatened to withdraw from the joint programs that were simultaneously spreading in GM's unionized plants and threatened job actions at GM's other plants if the issue of union recognition was not settled. (Katz, 1985: 90)

Of more lasting importance was the fact that in its non-union southern strategy plants GM first utilized its 'operating team' concept. This proved to be an important testing ground for concepts GM later spread to its other plants. The operating team system includes a team form of work organization with very few job classifications and a lessening in the role played by seniority, and contrasts sharply with traditional work practices used in the union sector.

The growth of non-union Japanese and German auto transplants has proved to be a particularly troubling problem for the UAW and a significant source of variation in employment relations in the auto industry. As can be seen from Table 1, the transplants now provide a sizeable percentage of total U.S. auto assembly production, and this will increase as the expansion plans underway in these plants are completed. Only transplants that are co-owned by an American company have been unionized. ${ }^{3}$ The UAW conducted an unsuccessful organizing drive in the Nissan plant, receiving only $30.5 \%$ of the vote in an NLRB representation election in 1989 and since has only been able to muster informal organizing efforts in the other transplants.

\section{Wages - Big Three Versus the Transplants}

Wage levels at the transplants vary between 80 to $90 \%$ of those at American-owned auto plants. For example, in January 1994 the hourly wage rate for assemblers at the Nissan and Honda transplants were, respectively, $\$ 15.08$ and $\$ 15.65$ (while they were $\$ 18.03$ at General Motors). In March 1996 , the hourly wage rate for assemblers at the BMW auto assembly plant in Spartanburg, South Carolina was $\$ 17.00$ (while it was $\$ 18.74$ at General Motors). ${ }^{4}$

\section{Eamings Variation Across the Non-union Auto Assembly Plants}

The small difference in the hourly wage rate at the Nissan and Honda transplants cited above is representative of the fact that wage rates have not varied significantly across the transplants. In the transplants a variety of performance-based pay supplement worker hourly earnings. These supple- 
ments generally range on the order of 5 to $20 \%$ of total worker pay although the form of the performance pay varies across the plants. Toyota's Georgetown assembly plant, for example, has two bonus systems that supplement hourly earnings. One bonus has been tied to plant performance and has produced flat rate bonus payments that varied between 8 to $12 \%$ of workers total hourly earnings between 1987 and 1994. (Adler 1995: 27; Mishina 1995: 16) ${ }^{5}$ Since 1990 at the Georgetown plant there has also been a 'discretionary bonus' paid annually at the discretion of the president of the company ranging from $\$ 600$ per worker in 1991 to $\$ 1400$ in 1993. At Honda's transplant operations, meanwhile, workers receive semi-annual bonuses that are based in part on the degree to which quality goals for the model year are being achieved. (MacDuffie, forthcoming: 28).

With regard to fringe benefits there are more substantial differences between the compensation package provided to hourly workers in the Big Three plants and the benefits provided in the transplants. The transplants, for example, tend to provide significantly more modest medical insurance and pension plans where the latter often include an individual retirement account or defined contribution plan rather than the more elaborate defined benefit programs found in the Big Three. Howes (1993: 46-50) and Ghilarducci (1991: Table 3, p.10) find, for example, that pension costs per worker-hour in 1987 were $\$ 2.63$ and $\$ .95$, respectively, at Ford and GM and $\$ .50$ and $\$ .43$, respectively, at the Honda and Toyota transplants.

Table 3. Percent of the Workforce Unionized in the U.S. Auto Parts Industry Estimates for Independent Parts Establishments in BLS Industry Wage Surveys

\begin{tabular}{cccc}
\hline 1963 & 1974 & 1983 & 1989 \\
82 & $80-84$ & 58 & 56
\end{tabular}

Estimates Using UAW Membership and SIC Employment Figures for Non-Big 3 Parts Plants

\begin{tabular}{ccccc}
\hline $1976-78$ & $1979-81$ & $1982-84$ & $1985-87$ & $1988-1990$ \\
60 & 56 & 40 & 27 & 23
\end{tabular}

CPS Estimates for Auto Parts Excluding Big 3

\begin{tabular}{crrrrrr}
\hline 1983 & 1984 & 1985 & 1986 & 1987 & 1988 & 1989 \\
20 & 26 & 20 & 21 & 15 & 21 & 18
\end{tabular}




\section{Work Practices at the Japanese Transplants}

All the Japanese transplants use the Japanese-oriented workplace approach including standardized jobs and problem solving teams. Given the fact that team systems have spread unevenly throughout the Big Three assembly plants as discussed below, the Japanese transplants use teams more extensively than the average Big Three plant and are distinguished by their use of a Japanese-oriented version of team systems. In the teams in Japanese transplants worker autonomy is relatively limited as team systems are oriented toward the identification and resolution of specific production problems. Furthermore, supervisors in the Japanese transplants tend to exert a strong role, a role that is more similar to the duties retained by supervisors in auto plants in Japan than it is to the facilitator role played by supervisors in American-owned assembly plants with team systems (using a joint team-based approach). In addition, Japanese transplants use standardized job assignments and although workers may participate in the development or refinement of these job assignments, work tasks are set in detail in these assignments and they are not, as is common in Big Three teams, subject to frequent informal modification by team members. Team leaders in the non-union Japanese transplants are selected by management and not through the involvement of team members.

The non-union Japanese transplants lack the formal grievance procedures used in the unionized American-owned auto plants to settle worker complaints and worker-supervisor disputes. In the transplants, supervisors are more active in settling disputes, often through informal channels. (Graham 1995: 108) At some of the Japanese transplants more formal procedures have been established to address worker complaints concerning discharges. At Honda, for example, a joint (worker and management) peer committee reviews disciplinary discharges and has reversed a high percentage of these discharges (Katz and MacDuffie 1994: 214).

Five of the six nonunion Japanese transplants also maintain committees of worker representatives (appointed by management) that provide a form of worker representation. (Pil and MacDuffie 1995: 7) Although these committees provide avenues for communication between workers and management, they clearly lack the independence and authority found in the grievance procedure and negotiated committee structures in the unionized auto plants.

\section{Variation Within the Unionized Auto Assembly Sector}

The extent of variation in wages and work practices is even larger in the unionized auto assembly plants. Understanding how variation in earnings 
and work practices has grown in the unionized Big Three auto assembly plants requires an awareness of the bargaining structure that has guided collective bargaining at the Big Three. In the traditional bargaining structure that prevailed at the Big Three auto companies compensation is set by national company-specific, and multi-year (since 1955 they have been three year) agreements. Some work rules such as overtime administration, employee transfer rights, and seniority guidelines are also set in the national contracts. Local unions, in turn, negotiate plant level agreements that supplement the national agreements. These local agreements define work rules such as the form of the seniority ladder, job characteristics, job bidding and transfer rights, health and safety standards, production standards, and an array of other rules that guide shop floor production. The local agreements do not regulate either wages or fringe benefits which are set in the national contracts. Some indirect influences on wage determination do occur at the plant level in the definition and modification of job classifications provided through the local agreements. Local bargaining over work rules allows for the expression of local preferences and in the face of the extreme economic pressures that confronted many plants from the 1980s on, local bargaining became increasingly important and volatile. ${ }^{6}$

\section{Eamings Determination in the Unionized Assembly Plants}

Formulaic mechanisms have been utilized to set wage levels in collective bargaining agreements in the Big Three. (Katz 1985: 14-16) The formulaic wage-setting mechanisms traditionally included in the company-wide collective bargaining agreements were an annual improvement factor (AIF) that after the mid-1960s amounted to 3 percent per year, and a cost-of-living adjustment (COLA) escalator that often provided full or close to full cost-of-living protection. The importance of these formulaic mechanisms is that they provided continuity in wage determination across time, and across the assembly companies at any given point in time. Continuity across the industry was provided by inter-company pattern following and by the fact that in the plants covered by the company-wide agreements, the national contract wage was not modified in local bargaining.

Along with increases in real hourly earnings, in the post World War Two period, until the 1980s auto workers received steady improvements in their fringe benefit package, and as noted above, a number of these fringe benefit advances spread to the auto supplier firms and to a number of other industries. Over the postwar period fringe benefits grew as a share of total worker compensation. 
Inter-company variation first appeared in the hourly wages paid by the Big Three in 1980 when Chrysler, under the threat of bankruptcy, negotiated pay concessions with the UAW that included the initial deferment, and eventual cancellation, of COLA and AIF payments. ${ }^{7}$ Pay concessions followed in the 1982-84 UAW contracts negotiated ahead of schedule at GM and Ford. Concessions in the contracts negotiated at Chrysler, Ford and GM in 1982, 1984 and 1987 included the substitution of lump sum pay increases for the traditional AIF base pay increases (although profit sharing was provided as a partial substitute for those base pay increases). These contracts included some relatively small differences in the timing of pay increases between Chrysler and the other two companies, in part as a result of the successful efforts of the UAW to get Chrysler to repay workers for the sacrifices they made in the 1980 contract.

The 1990-93 contracts provided identical pay increases across the Big Three (as did the subsequent 1993-96 and 1996-1999 contracts) which signaled a return to strict pattern bargaining in contractual base pay increases and lump sum wage payments. Hourly base pay rates were standardized even earlier across the Big Three and the short life of hourly pay differentials suggests how seriously the UAW pursued hourly base pay standardization . Right before the start of concession bargaining at Chrysler, as of the third quarter of 1979 , hourly base pay rates had been identical at the Big Three at $\$ 8.67$ (for assemblers). By the third quarter of 1983, the relatively large concessions at Chrysler had produced hourly base pay rates at GM, Ford, and Chrysler, respectively, of $\$ 11.85, \$ 11.86$, and $\$ 9.85$. In the first quarter of 1985 , special adjustments provided in the 1985 Chrysler-UAW contract raised the Chrysler hourly base pay rate back up to the rate being provided at that point at GM and Ford $(\$ 13.36){ }^{8}$

While the UAW fought hard to reinstate strict pattern following in base pay rates and contractual increases there was much dissension created among the work force over the fact that the introduction of profit sharing in the early 1980s had laid the groundwork for significant variation in worker earnings across the Big Three. The payouts of the profit sharing plans adopted in the Big Three from 1983 on, have varied substantially, in large part due to differences in the financial performance of the companies. (See Table 2) ${ }^{9}$ The profit sharing payouts between 1983 and 1995 at GM, Ford and Chrysler, respectively, totaled $\$ 3091, \$ 20,545$ and $\$ 16,650$ (as noted in Table 2). The annual payouts in the profit sharing plans have been quite large in some years. For example, in 1994 at GM, Ford, and Chrysler the respective profit sharing payouts were $\$ 550, \$ 4,000$ and $\$ 8,000$ per worker. 
Table 2. Big Three Average Worker Profit Sharing

\begin{tabular}{lrrr} 
Year & Ford & GM & Chrysler \\
\hline 1983 & $\$ 402$ & $\$ 605$ & $\$ 0$ \\
1984 & 1,993 & 515 & 0 \\
1985 & 1,262 & 329 & 0 \\
1986 & 2,177 & 0 & 0 \\
1987 & 3,762 & 0 & 0 \\
1988 & 2,874 & 242 & 725 \\
1989 & 1,025 & 50 & 0 \\
1990 & 0 & 0 & 0 \\
1991 & 0 & 0 & 0 \\
1992 & 0 & 0 & 425 \\
1993 & 1,350 & 0 & 4,300 \\
1994 & 4,000 & 550 & 8,000 \\
1995 & 1,700 & 800 & 3,200 \\
Total & $\$ 20,545$ & $\$ 3,091$ & $\$ 16,650$ \\
\hline
\end{tabular}

1 Chrysler workers received a $\$ 500$ contractual payment not tied to profits.

Source: Unpublished table prepared by the UAW Research Department, February 8, 1995.

Variation in earnings also has surfaced due to the uneven adoption of pay-for-knowledge schemes across auto plants and the variation that exists in the pay-for-knowledge plans that have been adopted. In some plants workers receive $\$ 1.25$ more per hour than other workers as a result of their progression to the top of a pay-for-knowledge scale (attained through a worker's mastery of all the jobs in their respective work area or performance as an hourly team coordinator).

Research has shown that unions often allow more substantial variation in fringe benefits than they allow in base pay increases presumably because variations in fringe benefits are more difficult to calculate and thus are somewhat less susceptible to comparisons made by the rank and file. The UAW followed this style in its bargaining with the Big Three in that substantial variation was accepted by the UAW in profit sharing payouts and in the use and form of pay-for-knowledge plans at the same time the UAW was working hard (and successfully) to eliminate variation in base pay increases across the Big Three.

\section{Work Rule Variation in Unionized Auto Assembly Plants}

Even greater variation now appears in the work practices used in unionized auto assembly plants. Sizeable variation in employment relations in assem- 
bly plants has occurred as a result of the fact that work rules and work organization have been modified in different ways and at a varied pace across auto assembly plants. The threat of increased employment loss due to either increased foreign sourcing of vehicles, plant closings due to excess capacity, or the out sourcing of certain operations all created pressures to lower costs and improve product quality. Ultimately, the pressure for increased inter-plant work rule divergence came from the same source as the pressure for inter-company pay variation, the fear that even greater losses in employment would result if previous policies were maintained. Companies often used investment decisions as explicit leverage for these changes, in a strategy unions saw as 'whipsawing', i.e. forcing plants to compete against each other through concessions.

Some of these work rule changes involved increases in the 'effort bargain' through a tightening of production standards. Other work rule changes include efforts to lower production costs by increasing the flexibility with which labor is deployed. Common examples of the latter include classification consolidation; limits imposed on job bidding rights; the use of work teams to promote multiskilling through job rotation; and a pushing down of certain responsibilities, such as quality inspection, to production workers on the shop floor.

At plants that were threatened with imminent closing the work rules were typically changed in a disorganized and ad hoc manner. The presence of excess capacity allowed management to directly pit assembly plants against one another in work rule concession bargaining. This happened frequently from the late 1980s to the early 1990s in GM (and commonly in parts plants across the Big Three as described later). Although the particular work rule changes made in any assembly plant at any particular moment varied widely, the trend across the Big Three companies over the last fifteen years has been to gradually shift from a traditional system of work organization to a joint team-based approach.

The traditional work system in assembly plants involved numerous job classification, a very heavy and highly structured role for seniority rights in job assignments (transfers, promotions, shift preferences etc.) and a clear separation in the responsibilities of workers and managerial employees. The joint team-based approach, in contrast, provides greater and broader responsibilities to the blue collar work force, in many instances involving workers in production, and in some cases, even in basic business decisions. The core of this approach is the work team typically led by an hourly team coordinator. As teams spread the number of supervisors has been reduced and the 
role of the remaining supervisors shifted to a coaching and facilitating role (although discipline did remain a key function of supervision).

The pace at which this joint team-based approach is spreading in the Big Three varies across the Big Three. General Motors has experimented most extensively with this approach by using initially non-union. 'Southern strategy' plants as a testing ground for the concept. In the early 1980s General Motors started spreading the team approach in its northern assembly plants, first in new facilities such as the Lake Orion and Hamtramack plants and then in the late 1980s GM management often made the use of a team approach a necessary precondition for the survival of what were then often redundant facilities. Ford and Chrysler were even more gradual in their implementation in the joint team-based approach in part because neither was building new assembly plants in the 1980s and 1990s and thus did not have the opportunity to experiment in greenfield sites, and in part because the GM experience of introducing teams in existing ('brownfield') plants did not always work out so well. ${ }^{10}$

Yet, by the early 1990s even at Ford and Chrysler's assembly plants a joint team-based approach was spreading. Both Ford and Chrysler management began pushing what they referred to as 'modern operating agreements' (MOA's) which included teams and weakened seniority rights. ${ }^{\text {.1 }}$

At the same time, not all Big Three assembly plants adopted team systems. For example, at GM the Linden, Doraville, and Wilmington assembly plants do not use teams as of early $1997 .^{12}$ In a 1994 survey of a number of U.S. auto assembly plants, MacDuffie and Pil (1995: 10 ) find that one-third of the Big Three assembly plants in their sample use a team system.

Substantial variation also appears in the programmatic details of how teams and other features of this approach are actually being implemented. In team plants, for example, there is wide variety in the procedures used to select team leaders and the role that hourly team members exert in that selection process. Some team plants use strict seniority rights to determine who serves as the hourly team coordinator while some other teams allow team members to directly elect their team coordinator. ${ }^{13}$ While in some other assembly plants there is a joint labor-management selection committee that screens and interviews candidates for the team coordinator position in a jointly-designed assessment procedure. ${ }^{14}$ Meanwhile, other plants (such as GM's Shreveport truck assembly plant) allow the teams to chose the team leader selection procedure and as a result the selection procedure varies by work group across the plant. The procedures used to select team leaders is no incidental matter. This is revealed by the fact that this selection 
procedure has been a key issue in disputes (some of which have entailed work stoppages) at the Ford-Dearborn and other Big Three assembly plants. $^{15}$

There is also wide variety across plants in the specific duties performed by team members and leaders. In some plants team members have the authority to directly contact and visit parts vendors to resolve production problems. A number of plants have put hourly workers on scrap and quality control tasks forces and freed workers from assembly line responsibilities to give them the time to carry out new duties. ${ }^{16}$ Pay-for-knowledge has been adopted along with teams in some plants to encourage workers to learn more jobs in their work area and in the process become more capable of understanding the linkages between jobs in and across work teams. The presence and form of pay-for-knowledge varies across plants which as noted earlier, provides a source of earnings variation across plants in contrast to the traditional work system that served to dampen such variation. Thus assembly plants of the Big Three differ in terms of whether they use the traditional or a joint team-based work system and there is much variation across team plants in terms of the specific way that teams are being introduced.

Team systems have led to increased variation in work organization and work practices across auto plants through their operation as well as a result of the varying structure of team administration. The purpose of team meetings is to have workers directly address production problems as they arise and in the process have workers provide input into plant operations in order to settle problems or avoid them in the first place. This process produces variety in plant operations as workers in one team adopt work modes that either suit their preferences or respond to a particular problem in a manner that differs from the way that workers in other teams (or workers who reside in a plant that does not use teams) carry out their work.

Along with the variation produced by team systems there is wide variation appearing across assembly plants in the role that workers play in business decisions. The existence of teams work organization is part of a deepening of worker involvement in business decisions. Yet, in many other ways not directly linked to teams per se, there is wide variety appearing in the role that workers and union officials are playing in plant operations. In broad terms there is a blurring occurring in the roles that workers and managers exercise in the plants. This blurring occurs, for example, when workers serve on a task force to solve a specific production problem and it also occurs when workers become part of in-sourcing, quality, scrap and the many other sorts of joint committees that are now typically a key part of each plant's administrative structure. In a number of Big Three assembly 
plants union officers now meet regularly with plant managers as business issues or crises arise, in some cases this participation extends to involvement in the preparation of a plant's long term business plans.

The broader involvement of workers and union officers in plant affairs has been spurred by a decentralization occurring within the ranks of management. As the negotiation of work practice change has intensified at the plant level and in the face of wide plant-level (and within-plant) variations that have appeared as a consequence of these negotiations, in unionized settings the influence of plant level industrial relations or employee relations managers has increased relative to their corporate counterparts. In addition, the involvement of operating managers (such as production managers or production superintendents) in employee relations matters has increased in part through the reduced role that the formal grievance procedure is playing in conflict resolution and the increasing role of informal discussions held between operating managers and workers (and union officers). Some of these discussions arise out of the natural operation of teams, while others occur as result of the broader roles workers are playing in problem solving forums or through the activities of the various joint committees operating on the shop floor.

In some plants a formal 'area' management structure is spurring the decentralization of industrial relations down to the shop floor. In these plants typically three or four key operational areas are designated and reporting lines are adjusted to fit these areas rather than the traditional plant hierarchy. In the traditional management structure labor relations staff report upward to the plant industrial relations (or personnel) director and not to an operating manager. In an area management structure, in contrast, the employee relations support staff report directly to an area operating manager and report in a matrix manner to an employee relations (or industrial relations) director. Area management represents a business-unit style of operation at the plant level and is intended to bring an awareness and responsiveness to cost and profit pressures down to the work area. This concept, used in plants such as Chrysler's Jefferson Avenue assembly plant, is leading to a reorganization of the employee relations function within management as well as a broader involvement of workers and union officers in plant operations.

The purpose of area management is to have the operations leaders of the work area take on more direct responsibility for employee relations issues and also have the employee relations staff learn about and respond more directly to business needs. In the process the staff function of industrial relations is being shifted downward inside the plant and also being diffused 
to operating managers who traditionally did not get directly involved in employee relations matters.

With this shift to area management and other more informal changes, management faces a number of human resource issues such as how to reshape reporting and training lines accordingly. For instance, the career development of industrial relations staff (and that of operating managers) has to be reshaped to accommodate the fact that industrial relations staff now are required to interact more extensively with operating managers and less often with higher level staff within their own functional area.

The most extensive decentralization of employment relations in a Big Three assembly plant (and perhaps the most extensive anywhere) occurs at the Saturn Corporation. Notably, this decentralization has led to extensive involvement by workers and union representatives in business issues at Saturn. ${ }^{17}$ The organizational structure of Saturn includes a number of committees, each of which includes worker or union representation. (Rubenstein, Bennett, and Kochan, 1992) At the shop floor level there are work units made up of 6 to 15 workers and a single production worker classification. Work units participate as a problem solving group and make decisions concerning job assignments, job rotation, overtime, and recruitment. Workers perform a variety of job tasks in their work area and also perform some of the planning and control tasks traditionally carried out by supervisors. At the top level of Saturn is a 'strategic advisory committee' that engages in long run business planning and includes the president of the UAW local union.

One of the most novel aspects of shop floor industrial relations at Saturn derives from the fact that the UAW contract governing the Saturn complex has no local seniority agreement. Thus, there is no formal role for seniority in matters such as job assignments, job bidding, overtime, and shift assignments. Most of these decisions are made informally by the work units (i.e., by workers themselves). Perhaps most revolutionary is the presence of union and management 'partners' who co-manage decisions within the Saturn complex. Although the union does not have a formal place on the GM Board of Directors which makes the ultimate decisions concerning Saturn's investments, products, and pricing, the strong role played by union partners at Saturn gives the union a level of involvement in decision making that is unparalleled in contemporary American industrial relations.

In a number of ways Saturn provides an extreme example of the work practices found in the joint team-based approach. Compared to Saturn, most auto plants (and plants in other industries as well) have less dramatically meshed worker and manager roles. At the same time the existence of Saturn, 
and the fact that other plants have in their own ways restructured work and labor and management roles, adds to the rich nature of the variety found across joint team-based plants.

Technology, managers' efforts to preserve their own role and control, and other factors still constrain the options available to workers and unions. Nevertheless, the spread of teams and other forms of participatory work reorganization are producing a significant increase in variation in work practices particularly where teams and the like are being linked to a decentralization within management structures.

\section{Industrial Relations in the Auto Parts Sector}

\section{The Boundaries of the 'Intemal' and 'Independent' Auto Parts Sector}

Variation in employment relations has increased in the auto parts sector in general terms in a manner similar to developments in the assembly sector. At the same time, a number of factors differ in these two sectors, in part due to differences in the timing and intensity of non-union employment growth. The 'internal' parts operations of GM, Ford, and Chrysler are the largest producers in the auto parts industry accounting for approximately $60 \%$ of the shipments in the motor vehicle parts and accessories industry. The internal parts plants follow the same bargaining structure as the assembly plants and nearly all are covered by the master company agreements negotiated between the Big Three companies and the UAW. ${ }^{18}$ Since they are covered by company-wide collective bargaining agreements, wage rates and fringe benefits at the internal parts plants are identical to those at the Big Three assembly plants.

In recent years Big Three company negotiators have frequently complained about the competitive pressures confronting the internal parts plants and have expressed the desire to create separate lower tier pay rates for the internal parts operations. The UAW has successfully resisted these demands, but the union has been less successful in constraining the outsourcing of parts production and the negotiation of work rule concessions. In line with the Big Three-UAW bargaining structure, there are separate local (often plant) agreements at the internal parts operations and from the early 1980s on there were major concessions negotiated in the work practices at the internal parts plants.

Substantial variation now appears in the work practices in the internal parts plants as some of these plants use teams and the form of teams and other methods of worker and union involvement in decision making also 
vary enormously across these plants. Major changes have occurred in work practices due to the enormous bargaining leverage management gained in the supplier sector as a consequence of outsourcing opportunities and the fact that alternative suppliers are often non-union with compensation that is significantly below that in internal parts plants.

\section{Declining. Unionization of Independent Auto Suppliers}

Since the growth of non-union competition has become such a significant factor in the auto parts industry, it is worth examining how non-union growth has occurred. The 'independent' parts companies, companies that produce auto parts but do not assemble those parts into final vehicles, were heavily, although never completely, organized with a lag behind the unionization of the Big Three. ${ }^{19}$ The percentage of the supplier plants with a majority of their workers covered by a collective bargaining agreement rose from $50-55 \%$ in 1940 to $95 \%$ in 1957 and unionization then produced a substantial rise in the earnings of organized workers. Mean earnings in the supplier firms relative to earnings in assembly firms rose from $87.5 \%$ to 95.3\% from 1940 to 1957. (Katz 1987)

Union coverage in the independent parts plants fell substantially from the mid 1970s on as illustrated by the figures in Table 3. The fall in unionization was a major cause of the decline in the earnings of workers in the independent parts firms relative to the earnings of workers in auto assembly plants. (See Table 4) Relative earnings declines occurred earlier

Table 4. Worker Earnings in the U.S. Auto Parts Industry Relative to Auto Assembly Plant Earnings

Average Hourly Earnings in Independent Parts Suppliers Relative to Earnings in Auto Assembly Firms

\begin{tabular}{ccccc}
\hline 1957 & 1963 & 1974 & 1983 & 1989 \\
95 & 89 & 78 & 68 & N.A.
\end{tabular}

Relative Hourly Earnings by Size of Establishment

\begin{tabular}{lccccc}
\hline & 1957 & 1963 & 1974 & 1983 & 1989 \\
50-499 workers & 86 & 77 & 67 & 62 & 56 \\
500 or more workers & N.A. & 97 & 85 & 75 & 66 \\
1000 or more workers & 99 & 101 & 94 & N.A. & N.A.
\end{tabular}

Source: All of these figures are from BLS industry wage surveys. The figures are reported in, 'The North American Auto Industry at the Onset of Continental Free Trade Negotiations,' Economic Discussion Paper 38, U.S. DOL, Bureau of international Affairs, July 1991, Table 24. 
and have been much larger in small firms. These earnings declines are probably linked to the fact that unionization declines were particularly large in small auto supplier firms. Many of the small parts firms pursued an employment relations strategy which entailed either low wage or bureaucratic non-union employment practices.

The push for concessions at the independent parts firms from the early 1980 s on was exacerbated by the fact that independent parts firms faced all the pressures that were impinging on the auto assemblers, lacked the financial resources of the assemblers, and faced more substantial growth in low wage domestic non-union competitors. Even in the face of a set of common pressures, substantial diversity emerged in the employment relations strategies pursued by independent parts firms, diversity influenced by business and union strategies and the degree to which new investments, or the lack thereof, gave management an interest in work reorganization and/or bargaining leverage.

\section{Eamings Variation Across Independent Parts Firms}

Negotiation outcomes at the Budd and Dana Corporations illustrate how the independent suppliers pulled away from the Big Three-UAW pattern and the cross-company variations created by this process. The UAW has been the dominant union at these companies since the later 1940s although a growing fraction of these company's plants operate on a nonunion basis. In their unionized plants over the post World War II period, Budd and Dana followed the pattern setting agreements at GM and Ford through the 1979 negotiations. Then in 1982, both supplier firms negotiated concessionary agreements with the UAW, and some of these concessions went beyond those negotiated at GM and Ford in the spring of 1982.

From 1983 to 1985 the contracts negotiated at Budd and Dana included deeper concessions than the agreements negotiated at the Big Three and also differed from one another in the timing and manner of these concessions. At Budd, employment had continued to decline after 1983. In response to this economic pressure, contracts with the UAW at Budd in 1985 included additional concessions and did not follow the 1984 pattern setting agreements at GM and Ford. In 1987 and then again in 1991, Budd further differentiated itself from the Big Three pattern by negotiating a four year agreement with lump sum and base pay increases that were one to two percent per year lower than the terms of the Big Three contracts. Profit sharing never has been included in either the Budd or Dana contracts, another important way in which these contracts differed from the Big Three settlements. The most recent UAW labor contracts at Budd and Dana differ 
even more substantially from one another and from the UAW's contracts with the Big Three auto companies.

Thus, the trend from the late 1980s on was for the independent auto supplier companies to gain deeper pay concessions than those being negotiated in this period at the Big Three companies. In addition, important differences appeared across the independent suppliers in the pay and fringe benefit concessions they each gained.

\section{Work Practice Variation in the Independent Parts Plants}

Corporate strategy and the extent to which new (often nonunion) investments gave management an interest in work reorganization and bargaining leverage influenced the evolution of work practices within independent auto parts companies in a manner not very different from developments in the assembly sector. As a result, there are now sizeable cross-company and cross-plant variation within auto supplier firms in their work practices and their relationships with unions (where union representation persists).

The Magna Corporation, for example, aggressively opened a number of small non-union plants in the 1980s and adopted a variant of a human resource management approach in those plants which includes team systems. (Walton, Cutcher-Gershenfeld and McKersie 1994: 121) TRW, in contrast, used acquisitions and investments (and disinvestment) to gradually transform itself over the post World War II period from a company with significant union representation to the current low level of union representation in its auto parts plants. In its non-union plants TRW uses team systems (and frequently pay-for-knowledge plans) along with other practices that fit the human resource management pattern. TRW's approach is noteworthy in the high degree of independence it grants to plant managers regarding work practice implementation. This decentralized approach to employment relations at TRW helps isolate the existing union operations from the growing non-union operations in the company. At the company's union plants generally a traditional (arms-length) employment pattern has been maintained.

A different corporate strategy toward work practices has appeared in the Budd Corporation's unionized auto parts plants which have been incrementally modifying their traditional work practices. These incremental modifications involve the introduction of on-line and off-line quality circles and increased direct communication between management (particularly supervisors) and workers. Notably, this incrementalist approach lacks a more radical restructuring of work organization or worker roles. Yet, at the same 
time Budd has been experimenting more aggressively with union avoidance in a greenfield non-union plant in Kentucky which utilizes a human resource management-type employment pattern. Adding to this diversity within Budd is the movement toward a joint team-based employment pattern at Budd's Phoenix plant (this movement started in the late 1980s). (Walton, Cutcher-Gershenfeld and McKersie 1994: 151)

Within the auto parts sector generally, as in the assembly sector, the spread of joint team-based or HRM approaches varies across and within companies. Generally, management has found it easier to gain concessions in parts plants where employment has been declining or where they could make credible threats of further employment declines. Another similarity with developments in the assembly sector arises from the fact that there is greater use of these workplace initiatives in new greenfield parts plants and a tendency for more incremental modification of traditional labor relations systems in older brownfield parts sites. ${ }^{20}$

\section{Problems From Increased Variation and the Associated} Decentralization of Industrial Relations

The local branches of the UAW have ended up with a lot of discretion regarding workplace issues. This is spurring experimentation and variety in local work rule changes. Yet, the absence of forceful national coordination of work rule bargaining also opens the door to managerial-led whipsawing in which plants are played off against one another in survival contests when the presence of excess capacity and production cutbacks shifts bargaining power to management.

Management typically initiates the workplace changes discussed in this chapter in an effort to improve costs, quality, and production flexibility in their plants. Data from assembly plants suggests that on average Japaneseoriented work practices have led to improvements in production costs and product quality. (MacDuffie 1995) Yet, there are a number of U.S. assembly plants that have attained relatively favorable production costs without resorting to such methods. (Babson 1995) These plants have retained many traditional work and industrial relations practices, but have modified those practices incrementally by gradually increasing, through informal channels, the amount of worker (and union) involvement in plant operations. In some cases increased worker input has come in these plants through the heightened use of existing suggestion programs. In these 'incrementalist' plants job classifications have often been simplified and reduced although not through the introduction of team methods. Cost improvements also have 
come in the incrementalist plants (as in the Japanese-oriented plants) through changes in management methods that reduce the number of parts and simplify the assembly process as well as through improvements in technology (the same is true for plants that radically restructured work organization).

The successes achieved in plants that adopted at incremental approach to work restructuring have created doubts within the ranks of both managers and union officers as to whether more extreme work practices changes are necessary in order to maintain profitability and employment. (Lee 1996) These doubts have been enhanced by the fact that more radical work practice reform efforts did not always work out well in the auto assembly sector. Research suggests, for example, that the introduction of formal team systems in GM assembly plants in the early and mid 1980s led to deteriorations, and not the expected improvements, in productivity on average even though there were a few assembly plants in GM where team systems did lead to substantial performance improvements. (Katz, Kochan, and Keefe 1987) The inability of teams to always improve productivity may have been associated with the fact that team plants did not in all cases lead to substantive increases in worker involvement in decision making and workers and unions in many of the plants resented that they had agreed to introduce teams only as a result of managements' threats to otherwise close the plant. Incrementalism in changing employment relations also was promoted by the fact that the financial success of Ford in the late 1980s and Chrysler in the early 1990s seems to have rest primarily on successful product design and not as a result of particularly successful work practice initiatives. $^{21}$

Thus, managers and unionists were not convinced by the mid 1990s that work practice initiatives were essential for financial success and they were confused as to whether and how changes in work practices would affect economic performance. The presence of this confusion helps explain why there has been (and continues to be) so much variation in the workplace initiatives being pushed by management. Given that corporate (and central union) officials are uncertain of the advantages of a particular work practice, the initiative for change is typically left up to plant-level actors. This shifts the locus for change to the plant level.

Overall, management benefited greatly from the shift toward locallydriven workplace initiatives as these initiatives have led to lower costs and improved product quality, even in the face of the parties' confusion regarding the sources of improvements. Yet, when demand for Big Three products improved and capacity constraints tightened in the early 1990s, at some 
plants management lost its bargaining leverage and localized bargaining turned back into a process of union-led whipsawing. This was well illustrated by events in the early and mid 1990s at GM when the UAW conducted a series of strikes at parts plants. A strike at the Dayton brake plant of GM in the spring of 1996 was the most well publicized of these strikes as it led to the closure of nearly all of GM's assembly plants. The specific issue that precipitated each of these strikes varied, but the common thrust of these strikes was efforts by the UAW to acquire more extensive employment security guarantees at the plant level.

\section{Increased Decentralization and Diversity in Other Industries as Well}

Variation in employment relations is growing in the United States as a product of the growth in non-union employment and the existence of a variety of union and non-union employment patterns. Similar trends are apparent in other parts of the U.S. economy (and in other industrialized economies). (Darbishire and Katz, 1997) The auto industry is distinguished by their high levels of union representation (which as elsewhere are declining) but not by the processes through which variation in employment relations is appearing. The breakdown of pattern bargaining across firms and industries in the union sector, and the spread of contingent forms of pay and associated greater reliance on individualized rewards are all contributing to increased variation in pay. These changes in pay practices have contributed to the unusually large increases in income inequality in the United States. (see Darbishire and Katz, 1997)

While team systems have spread and operate as a critical part of the sophisticated HRM and joint team-based patterns, more traditional forms of work organization continue in firms following the low wage, bureaucratic, and New Deal employment patterns. Meanwhile, work practices variation is being spurred by a decentralization in managerial and corporate structures. Management is eager to pursue this decentralization and link it to more direct involvement of the workforce in business decisions and new communication strategies. However, in union settings when bargaining power has shifted back towards labor's advantage, decentralization has not so clearly worked to management's advantage. Furthermore, the labor movement has occasionally been able to use decentralized bargaining to whipsaw management, more often than not, union weakness has been both a precondition and consequence of collective bargaining decentralization. Decentralization, more direct management-employee communication, and 
increased employee (and union) involvement in business decisions thus all have contributed to the wide variation appearing in work practices.

No one employment pattern is dominating in the United States, in part because management is unsure of the performance advantages of the various employment patterns. Management's indecisiveness has been fueled by the mixed objective evidence regarding performance effects and the fact that the effects of employment practices seem to be linked so closely to business (and labor) strategies. What is most striking about U.S. developments is the wide variation appearing within and across employment patterns and the auto industry provides a clear illustration of this growing variation.

\section{Notes}

1. 30 and out pensions provide that a worker can retire and receive pension benefits after 30 years of service no matter what their age.

2. We were not able to identify official Big Three employment or UAW membership statistics. The figures cited in the paper are from unpublished UAW series, various years.

3. Although the unionized Mitsubishi plant in Illinois is now solely owned by a Japanese company it was at one time owned jointly by Mitsubishi and the Chrysler Corporation.

4. These figures are the maximum hourly wage rates for production workers. When first hired workers at the transplants and at Big Three auto plants receive lower hourly wage rates that are increased step-wise over time according to fixed schedules. The transplant figures cited in the text were collected at the respective plants during interviews while the General Motors figures are reported in an unpublished wage series maintained by the UAW.

5. The company has plans to shift to a bonus based on a combination of individual and plant performance, but Georgetown managers are hesitant to introduce individual variation into the bonus system. The latter was conveyed to Harry Katz in a personal communication with Paul Adler in March 1996.

6. In this system the grievance procedure with binding third party arbitration serves as the end point of contract administration although disputes concerning production standards, new job rates, and health and safety issues are not resolved through recourse to grievance arbitration. Rather, the union retains the right to strike over these matters.

7. These concessions were negotiated in three rounds of bargaining conducted under pressure from the U.S. Congress which had just agreed to provide Chrysler with loan guarantees.

8. These figures are from an unpublished wage and COLA series maintained by the Research Department of the UAW.

9. For a while there were differences in the way profit sharing was calculated in the Big Three profit sharing plans. Under pressure from the UAW, in response to 
pressures from disgruntled workers at GM, the profit sharing formulas were standardized across the three companies.

10. See Katz, Kochan and Keefe (1987) for evidence regarding the problems GM had with the introduction of teams.

11. Chrysler management also has been pushing 'progressive operating agreements' which differ from the modern operating agreements in that these plants do not change work organization and worker and union roles as formally as MOA plants. (MacDuffie 1994: 82)

12. See (Milkman 1997) for discussion of developments at Linden.

13. The GM Tarrytown and Arlington assembly plants use strict seniority to select hourly team leaders.

14. In this procedure seniority is determinant if candidates have equal assessment scores. The GM Lansing agreement outlines such a procedure.

15. Disputes over team leader selection have occurred at transplants such as the Ford-Mazda Flat Rock and Ford Dearborn plants (Babson 1995).

16. Time clocks and factory gate restrictions have been eliminated in a number of plants to convey a spirit of increased worker autonomy and responsibility.

17. Saturn, a subsidiary of GM, is a complex of plants in Spring Hill, Tennessee.

18. In a small percentage of Big Three auto parts plants workers are represented by unions other than the UAW such as the IUE or the IAM.

19. The largest independent auto parts producing firms as of the mid 1990s are: Borg Warner, Budd, TRW, and Rockwell International.

20. These adjustments fit the pattern outlined in Katz and MacDuffie (1994: 205-208). Also see Cutcher-Gershenfeld (1994) for evidence regarding the diversity in employment relations surfacing across auto suppliers.

21. In the mid and late 1980s Ford benefited from the success of the Taurus, Explorer and a number of strong selling truck models while Chrysler's success in the 1990 was driven in large part by the success of their mini-van, the LH model, and a number of truck lines.

\section{References}

Adler, Paul (1995) 'Hybridization of HRM: Two Toyota Transplants Compared,' unpublished paper, School of Business Administration, University of Southern California, November.

Babson, Steve (1995) 'Whose Team? Lean Production at Mazda U.S.A.', in S. Babson (ed), Lean Work: Empowement and Exploitation in the Global Auto Industry, Wayne State University Press, Detroit.

Cutcher-Gershenfeld, Joel (1994) 'Collective Bargaining in the North American Auto Supply Industry,' in P. Voos (ed), Contemporary Collective Bargaining, IRRA, Madison, WI.

Darhishire, Owen and Harry C. Katz (1997) 'Converging-Divergencies: Worldwide Changes in Employment Relations,' NYSSILR, Cornell University, manuscript.

Ghilarducci, Teresa. (1991) 'Changing Pension Norms: The Case of Japanese Auto Transplants and U.S. Auto Firms,' unpublished paper, Department of Economics, University of Notre Dame, April.

Graham, Laurie (1995) On the Line at Subaru-Isuzu, ILR Press, Ithaca, New York. 
Howes, Candace (1993) Japanese Auto Transplants and the U.S. Automobile Industry, Economic Policy Institute, Washington, D.C.

Katz, Harry C. (1985) Shifting Gears, MIT Press, Cambridge, Mass.

Katz, Harry C. (1987) 'Automobiles,' in D. Lipsky and C. Donn (eds), Collective Bargaining in American Industry, D.C. Heath and Co., Lexington, Mass.

Katz, Harry C., Thomas A. Kochan and Jeffrey H. Keefe (1987) 'Industrial Relations and Productivity in the U.S. Automobile Industry,' Brookings Papers on Economic Activity, Vol. 3, Washington, D.C.: The Brookings Institution, pp. 685-728.

Katz, Harry C. and John Paul MacDuffie (1994) 'Collective Bargaining in the U.S. Auto Assembly Sector,' in P. Voos (ed), Contemporary Collective Bargaining.

Lee, Byoung-Hoon (1996) 'Workplace Transformation at Incrementalist Plants: A Cross-National Comparative Study of a Ford and a Hyundai Plant,' unpublished Ph.D. dissertation, Cornell University.

MacDuffie, John Paul (1995) 'Human Resource Bundles and Manufacturing Performance: Organizational Logic and Flexible Production Systems in the World Auto Industry,' Industrial and Labor Relations Review, 48, 2 (January).

MacDuffie 'Organizational Influences on Process Quality Improvement: Shop-Floor Problem-Solving in Auto Assembly Plants,' Management Science (forthcoming).

Milkman, Ruth (1997) Farewell to the Factory, University of California Press, Berkeley and Los Angeles.

Mishina, Kazuhiro (1995) 'What is the Essence of Toyota's Manufacturing Capability: Self-Management by the Transplant in Kentucky, 1986-1994,' in Communications: Hybridization of Industrial Models, GERPISA, Paris.

Pil, Fritz K. and John Paul MacDuffie (1995) 'Japanese and Local Influences: Human Resource Practices of Japanese Transplants in North America,' unpublished paper, Wharton School, University of Pennsylvania, November.

Rubinstein, Saul, Michael Bennett, and Thomas Kochan (1993) 'The Saturn Partnership: Co-Management and the Reinvention of the Local Union,' in B. Kaufman and M. Kleiner (eds), Employee Representation: Altematives and Future Directions, IRRA, Madison, WI.

Walton, Richard E., Joel E. Cutcher-Gershenfeld, and Robert B. McKersie (1994) Strategic Negotiations, Harvard Business School Press, Boston. 